\title{
Process Design of a Novel Low Temperature Methanol Synthesis Process Using an Air-blown Autothermal Reformer
}

\author{
Christian Ahoba-Sam, Lars Erik Øi, Klaus-Joachim Jens \\ Department of and Process, Energy and Environmental Technology, University College of Southeast Norway, \\ Norway \\ lars.oidusn.no
}

\begin{abstract}
Methanol $(\mathrm{MeOH})$ synthesis at low temperature (100 $\left.{ }^{\circ} \mathrm{C}\right)$ presents an opportunity for full syngas conversion per pass. This presents a cheaper alternative for $\mathrm{MeOH}$ synthesis using an air-blown autothermal reformer (ATR) rather than the conventional high temperature $\left(>250{ }^{\circ} \mathrm{C}\right) \mathrm{MeOH}$ synthesis approach which requires an expensive cryogenic $\mathrm{O}_{2}$-blown ATR. The aim of this work was to use the process simulation program Aspen HYSYS to simulate and optimize the reactor conditions for a complete $\mathrm{MeOH}$ process design using an air-blown ATR. Our results revealed that, while syngas produced from 'normal' air-blown ATR (syngas composition $0.20 \mathrm{CO}: 0.40 \mathrm{H}_{2}: 0.39 \mathrm{~N}_{2}$ ) required 100 bar to obtain full conversion per pass, syngas produced from enriched airblown ATR (syngas composition 0.31CO:0.62 $\mathrm{H}_{2}: 0.07$ $\mathrm{N}_{2}$ ) required 60 bar total syngas pressure to achieve the same. Even though the energy generated in both processes was enough to cover the heating demand in the total process with surplus, the enriched air-blown system provides a better energy recovery if the surplus energy is not used for extra power generation. The total process energy demand due to compression was estimated to be 2270 and $983 \mathrm{MJ} /$ ton $\mathrm{MeOH}$ product for the normal air-blown and enriched air-blown systems respectively. A process design was proposed based on the optimized conditions for the enriched air-blown process.
\end{abstract}

Keywords: Air-blown reformer, syngas, methanol, low temperature, simulation, Aspen HYSYS

\section{Introduction}

Methanol $(\mathrm{MeOH})$ is a multi-purpose molecule widely used as a base chemical, and for storage of energy and $\mathrm{CO}_{2}$ (Olah, 2005). $\mathrm{MeOH}$ can be used as a fuel blend or directly converted to valuable hydrocarbons such as gasoline over acidic microporous materials (Olsbye et. al., 2012), thereby providing an alternative source of petrochemical feedstock used today.

The current technology for $\mathrm{MeOH}$ synthesis is based on conversion of syngas and operates around 250$300{ }^{\circ} \mathrm{C}$ and 50-100 bar (Hansen \& Højlund Nielsen, 2008). While this technology is highly optimized, the relatively high operating temperature limits conversion to barely $20 \%$ per pass due to thermodynamics of the exothermic $\mathrm{MeOH}$ synthesis reaction (Equation (1)). As a result, the current process requires several recycling steps to optimize production (Lange, 2001).

Furthermore, the low conversion per pass of this process requires the use of a rather 'pure' syngas other than a $\mathrm{N}_{2}$-diluted syngas for the $\mathrm{MeOH}$ synthesis. Such pure syngas production alone accounts for more than half of the total operation and capital cost in current methanol processes (Marchionna et. al., 1998). This is due to the use of expensive cryogenic $\mathrm{O}_{2}$ for partial oxidation of hydrocarbons. The lowest cost of syngas production is by the use of either an ordinary air or an $\mathrm{O}_{2}$ enriched air rather than a cryogenic $\mathrm{O}_{2}$-blown autothermic reformer (ATR) (Hansen \& Højlund Nielsen, 2008). The highly exothermic syngas conversion to $\mathrm{MeOH}$ requires a relatively low temperature to achieve a full conversion per pass. Hence, such a low temperature process will allow for the use of $\mathrm{N}_{2}$-diluted syngas for $\mathrm{MeOH}$ production, with reduced capital and operation cost as there will be no need for recycling.

$$
\mathrm{CO}+2 \mathrm{H}_{2} \rightleftharpoons \mathrm{CH}_{3} \mathrm{OH} \quad \Delta \mathrm{H}=-90.6 \frac{\mathrm{kJ}}{\mathrm{mol}}
$$

Alternatively, a low temperature $\mathrm{MeOH}$ synthesis (LTMS) process which proceeds rapidly in a liquid medium at about $100{ }^{\circ} \mathrm{C}$ presents the possibility for full syngas conversion per pass (Christiansen, 1919). The LTMS process is known to occur in two steps (Equations (2) and (3)), via a methyl formate intermediate (Ohyama \& Kishida, 1998). Typically alkali alkoxide is known to catalyse the carbonylation step (Equation 1) and $\mathrm{Cu}$ based materials catalyse the hydrogenolysis step (Equation 2). Cu nanoparticles due to largely exposed surface area accelerate the hydrogenolysis step in the LTMS process (Ahoba-Sam, Boodhoo, et. al., 2018). For example, in diglyme solvent, $\mathrm{Cu}$ nanoparticles in combination with sodium methoxide led to up to $92 \%$ conversion per batch with 20 bar syngas composed of $0.33 \mathrm{CO}: 0.67 \mathrm{H}_{2}$, at $100{ }^{\circ} \mathrm{C}$ (Ahoba-Sam, Olsbye, et. al., 2018).

$$
\begin{aligned}
& \mathrm{CO}+\mathrm{CH}_{3} \mathrm{OH} \rightleftharpoons \mathrm{HCOOCH} \mathrm{H}_{3} \\
& \mathrm{HCOOCH}_{3}+2 \mathrm{H}_{2} \rightleftharpoons 2 \mathrm{CH}_{3} \mathrm{OH}
\end{aligned}
$$

In this paper, our focus was to design a complete process for the LTMS reaction using Aspen HYSYS simulation 
program. Considering that the LTMS process can tolerate $\mathrm{N}_{2}$ diluent, the use of ordinary air and other $\mathrm{O}_{2}$ enriched air can be simulated for the syngas production, and subsequently be used to design a complete $\mathrm{MeOH}$ plant. Even though the concept has been described as a 'dream reaction' (Hansen \& Højlund Nielsen, 2008), the current work demonstrates that the suggested concept is feasible. The specific aim of this work was to simulate and optimize the reactor conditions in order to propose a complete design of the LTMS process using an airblown ATR. Different parameters such as chemical compositions, temperature and pressure in the reactors were varied to optimize the process parameters.

\section{Process Description}

\subsection{Principles of the Syngas Production}

The syngas production process involved partial oxidation of methane $\left(\mathrm{CH}_{4}\right)$ using air, illustrated in Equation (4). The Figure 1 shows a syngas production process using air as the source of $\mathrm{O}_{2}$. The process consists of a reactor (ATR), compressor and heat exchangers. Compressed air was used to make-up for the stoichiometry between $\mathrm{CH}_{4}$ to $\mathrm{O}_{2}$. The $\mathrm{CH}_{4}$ feed used was assumed to be pure, without any sulphur or heavier hydrocarbon present, while the air feed consisted of only $\mathrm{O}_{2}$ and $\mathrm{N}_{2}$ to simplify the simulation. The compressed air together with the $\mathrm{CH}_{4}$ feed were pre-heated and fed directly into the reactor.

$$
\mathrm{CH}_{4}+\frac{1}{2} \mathrm{O}_{2} \rightleftharpoons \mathrm{CO}+2 \mathrm{H}_{2} \quad \Delta \mathrm{H}=-36 \frac{\mathrm{kJ}}{\mathrm{mol}}
$$

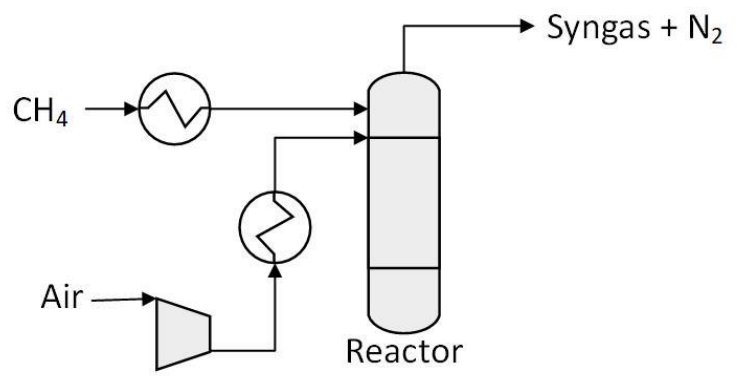

Figure 1. Principle for the syngas production process

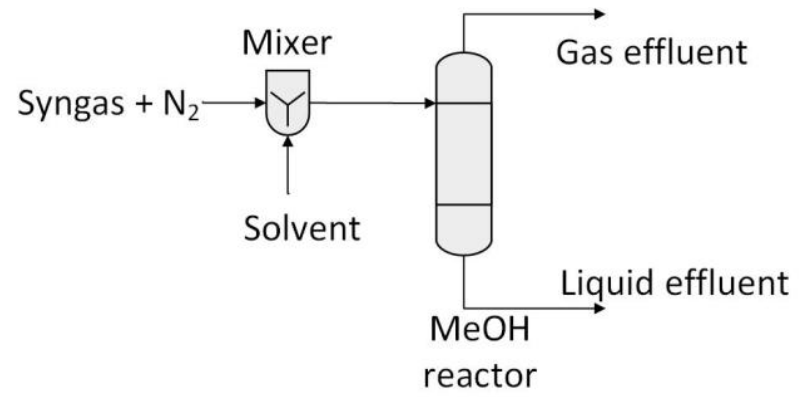

Figure 2. Principle for the low temperature $\mathrm{MeOH}$ synthesis process

\subsection{Principles of the MeOH Synthesis Process}

Figure 2 shows the $\mathrm{MeOH}$ synthesis process using $\mathrm{N}_{2}$ containing syngas as feed. The LTMS process involved a $\mathrm{MeOH}$ reactor and a mixing unit. Since this step is highly exothermic (see Equation (1)) and requires lower operating temperature, the process is often carried out in liquid medium to absorb excess heat to minimize adiabatic rise in temperature beside other solvent's polarity role for the catalysis (Ahoba-Sam et. al., 2017). The syngas feed is mixed with a liquid solvent and fed into the $\mathrm{MeOH}$ reactor. For simplicity of the model, we have taken $\mathrm{MeOH}$ as a solvent and due to the $100 \%$ thermodynamic syngas conversion, we have neglected the effect of $\mathrm{MeOH}$ solvent in the equilibrium calculations.

\section{Models}

All the simulations were performed using the Aspen HYSYS (version 8.6) program. Gibbs reactors were employed for both the syngas production and LTMS processes. A Gibbs reactor calculates the composition with the theoretical free energy minimum, which is the theoretical equilibrium composition. The PengRobinson equation of state (Peng \& Robinson, 1976) fluid package was used in all the simulations. The equilibrium for the partial oxidation of $\mathrm{CH}_{4}$ was calculated for the process in the ATR reactor, while $\mathrm{CH}_{4}$ was assumed to be inert in the $\mathrm{MeOH}$ reactor. After the individual reactors were optimized, an overall system was designed.

Separating units were added in the overall system to represent, (i) a pressure swing adsorber (PSA) and (ii) $\mathrm{H}_{2} \mathrm{O} / \mathrm{CO}_{2}$ absorber. The PSA was included to help regulate the $\mathrm{O}_{2} / \mathrm{N}_{2}$ composition that is fed into the ATR. The $\mathrm{H}_{2} \mathrm{O} / \mathrm{CO}_{2}$ absorber was used to separate the $\mathrm{H}_{2} \mathrm{O}$ and $\mathrm{CO}_{2}$ from the syngas effluent before the $\mathrm{MeOH}$ reactor. After establishing reasonable pressure and temperature conditions in the individual reactors, the total compression, and heating requirements were simulated, to find out whether additional heating was necessary for the total process.

\section{Process Simulations}

\subsection{Simulation and Optimization of the ATR for Syngas Production}

To optimize the feed composition, different mole fractions of the $\mathrm{CH}_{4}$ : air (containing $\mathrm{O}_{2}$ and $\mathrm{N}_{2}$ ) were fed into the ATR reactor. The $\mathrm{O}_{2} / \mathrm{N}_{2}$ ratio was kept constant at air composition of $21 / 79$. The Figure 3 shows the effect of the ratio of $\mathrm{CH}_{4} / \mathrm{O}_{2}$ on the syngas produced at $600{ }^{\circ} \mathrm{C}$. The highest amount of $\mathrm{CO}+\mathrm{H}_{2}$ coupled with the least $\mathrm{H}_{2} \mathrm{O}$ and $\mathrm{CO}_{2}$ side product (3 and $1 \%$ respectively) was observed at $\mathrm{CH}_{4} / \mathrm{O}_{2}=2$. While $\mathrm{H}_{2} \mathrm{O}$ and $\mathrm{CO}_{2}$ side products increased below the $\mathrm{CH}_{4} / \mathrm{O}_{2}=2$ 
ratio due to increase in oxidation, lower $\mathrm{CH}_{4}$ conversion was observed at higher $\mathrm{CH}_{4} / \mathrm{O}_{2}$ ratio as the amount of $\mathrm{O}_{2}$ became limiting. When the ratio of $\mathrm{CH}_{4} / \mathrm{O}_{2}$ was kept constant and $\mathrm{O}_{2} / \mathrm{N}_{2}$ ratios were varied (not shown), no variation was observed in the composition of the products. Overall $\mathrm{CH}_{4} / \mathrm{O}_{2}=2$ was chosen as a reasonable composition as this gave the highest amount of syngas $\left(\mathrm{CO}+\mathrm{H}_{2}\right)$ with $\mathrm{H}_{2} / \mathrm{CO}=2$.

The temperature was varied to determine a reasonable temperature required for the feed inlet. Figure 4 shows the effect of temperature on the syngas produced between 600 to $1600{ }^{\circ} \mathrm{C}$. This was done at $0.30 \mathrm{CH}_{4}: 0.15 \mathrm{O}_{2}: 0.55 \mathrm{~N}_{2}$ feed composition set to $20 \mathrm{bar}$. Generally, the overall $\mathrm{CH}_{4}$ conversion increased while side products decreased with increasing temperature. After $1200^{\circ} \mathrm{C}$, subtle changes were observed in the main products such that both the amount of syngas and $\mathrm{H}_{2} / \mathrm{CO}=2$ were similar. The amount of $\mathrm{H}_{2} \mathrm{O}$ and $\mathrm{CO}_{2}$ side product at $1200{ }^{\circ} \mathrm{C}$ decreased from 0.36 and $0.06 \%$ to 0.06 and $0.01 \%$ respectively at $1600{ }^{\circ} \mathrm{C}$. Nevertheless, considering the exothermic nature of the process and its significance on the reactor material, 1200 ${ }^{\circ} \mathrm{C}$ was the temperature of choice for the syngas production.

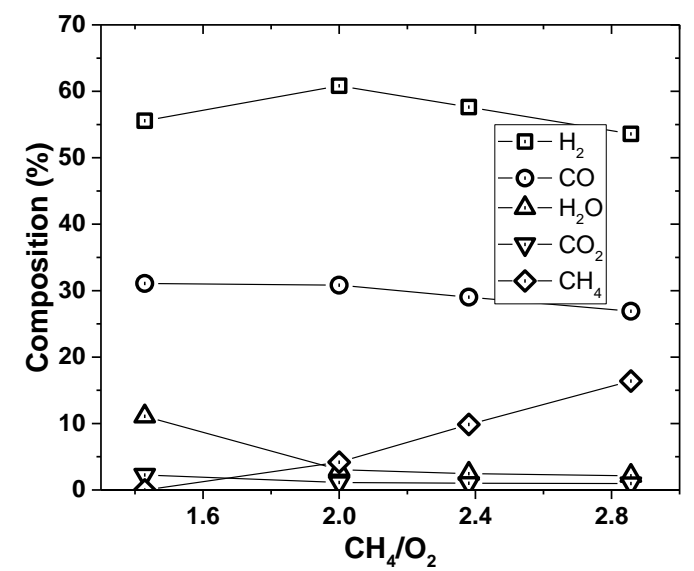

Figure 3. Effect of feed composition on the syngas production, at $600{ }^{\circ} \mathrm{C}$ and 10 bar.

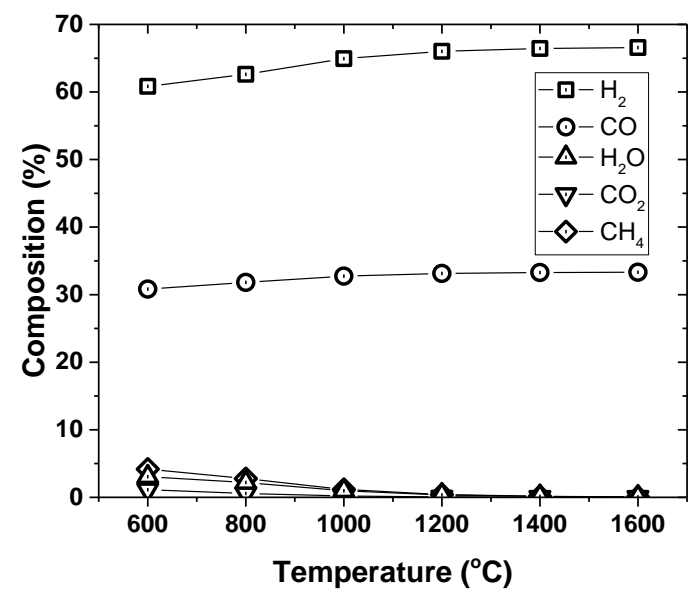

Figure 4. Effect of temperature on the syngas production, 20 bar
Furthermore, the total inlet pressure was varied to determine a reasonable pressure required for the optimal feed inlet. Figure 5 shows the effect of pressure on the syngas produced between 10 to 100 bar. This was done using similar syngas composition as was done for the temperature $\left(0.30 \mathrm{CH}_{4}: 0.15 \mathrm{O}_{2}: 0.55 \mathrm{~N}_{2}\right)$ at $1200{ }^{\circ} \mathrm{C}$. The overall $\mathrm{CH}_{4}$ conversion increased while side products decreased with decreasing pressure. After 30 bar, no significant changes were observed as both the amount of syngas produced and $\mathrm{H}_{2} / \mathrm{CO}=2$ remained the same. Therefore 20 bar was a reasonable pressure of choice for the syngas production.

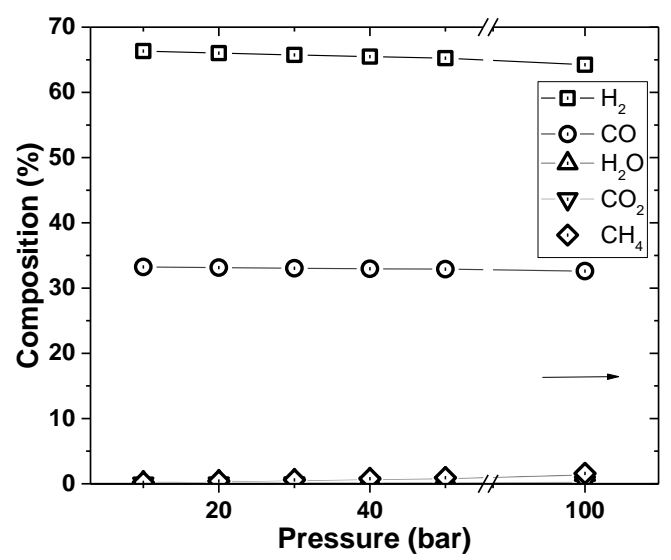

Figure 5. Effect of pressure on the syngas production

\subsection{Simulation and Optimization of the MeOH Synthesis Process}

The operating conditions for $\mathrm{MeOH}$ production was simulated to optimize the LTMS process. Figure 6 shows the effect of temperature on conversion at 20 and 100 bar syngas pressure. This was calculated using syngas ratio of $0.21 \mathrm{H}_{2}: 0.41 \mathrm{CO}: 0.39 \mathrm{~N}_{2}$. The syngas conversion rose exponentially from $300{ }^{\circ} \mathrm{C}$ to $120{ }^{\circ} \mathrm{C}$ and then increased slightly with decreasing temperature. The optimum temperature however depends on the operating pressure as the 20 and 100 bar syngas pressures showed similar trend but different conversions.

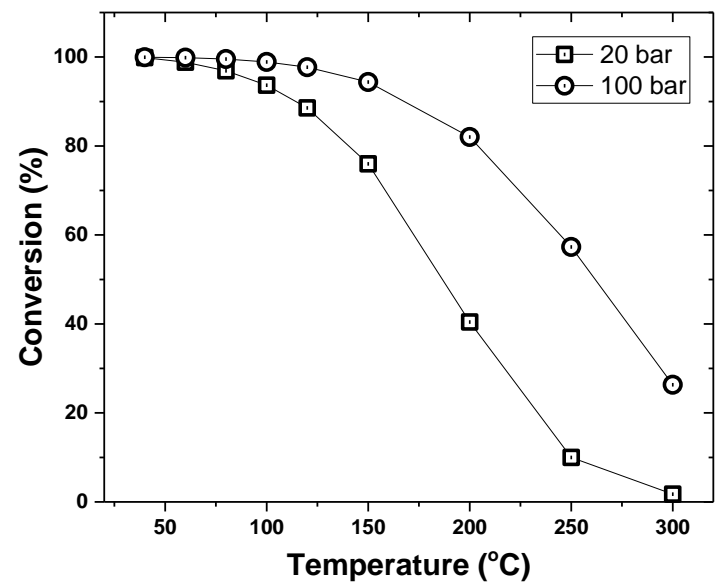

Figure 6. Effect of temperature on the LTMS process 
Figure 7 shows the effect of pressure with and without $\mathrm{N}_{2}$ at $100{ }^{\circ} \mathrm{C}$. The conversion with $\mathrm{N}_{2}$ was calculated using $0.21 \mathrm{H}_{2}: 0.41 \mathrm{CO}: 0.39 \mathrm{~N}_{2}$ syngas ratio while the conversion without $\mathrm{N}_{2}$ was calculated based on $0.67 \mathrm{H}_{2}: 0.33 \mathrm{CO}$ composition. The syngas without $\mathrm{N}_{2}$ showed more than $99 \%$ conversion from 5 to $100 \mathrm{bar}$ total syngas pressure. The syngas with $\mathrm{N}_{2}$ however exponentially increased with pressure such that about 99 $\%$ conversion was achieved at 100 bars. This indicated the importance of $\mathrm{N}_{2}$ diluent on the partial pressures of the syngas composition required for optimal conversion. Nevertheless, a reasonable pressure chosen for achieving optimal conversion in the presence of $39 \%$ $\mathrm{N}_{2}$ syngas diluent was 100 bar.

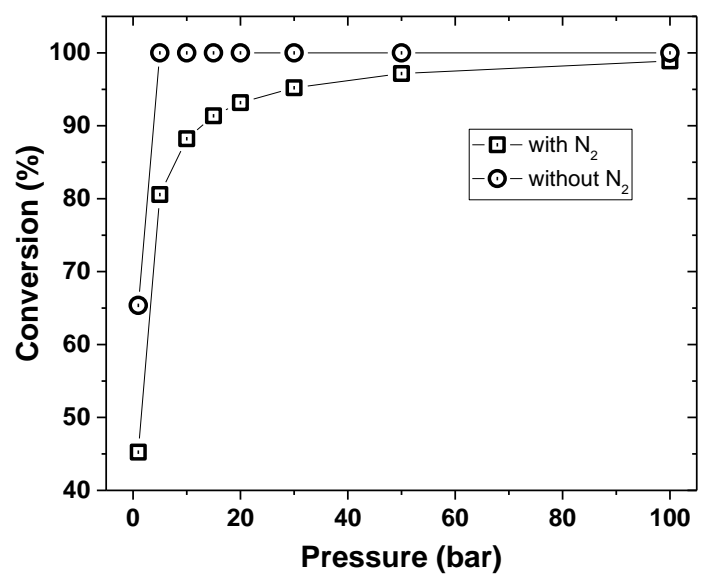

Figure 7. Effect of pressure on the LTMS process

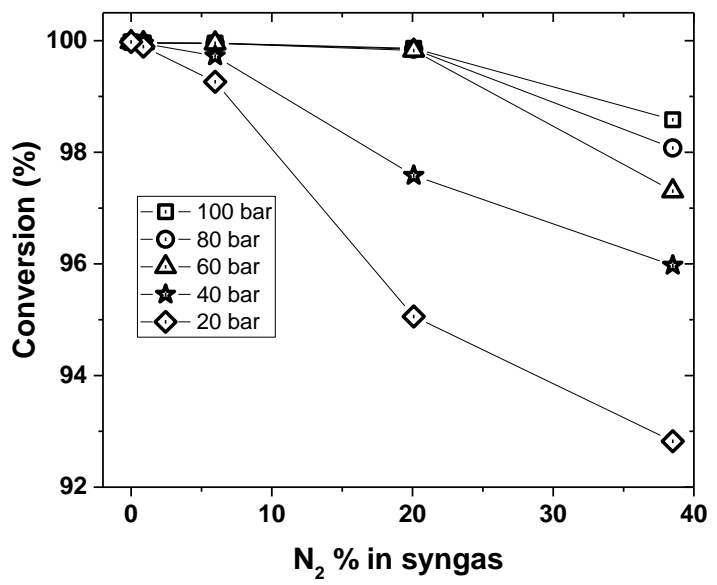

Figure 8. Effect of $\mathrm{N}_{2}$ diluent concentration on LTMS process at different pressures

Furthermore, the importance of $\mathrm{N}_{2}$ diluent was determined by varying its composition in the syngas. Figure 8 shows the effect of $\mathrm{N}_{2}$ composition in the $\mathrm{MeOH}$ synthesis at $100{ }^{\circ} \mathrm{C}$ at different syngas total pressures. Syngas conversion increased with decreasing the amount of $\mathrm{N}_{2}$ diluent in the syngas. Interestingly, a slight decrease of the amount of $\mathrm{N}_{2}$ in the syngas from $39 \%$ (from normal air composition) to $20 \%$, leads to full conversion even at 60 to 100 bar. Further $\mathrm{N}_{2}$ reduction below $7 \%$ in syngas will thermodynamically allow more than $99 \%$ conversion at $100{ }^{\circ} \mathrm{C}$ and $20-100$ bar. PSA for example can easily be used to enrich air up to $90 \% \mathrm{O}_{2}$ content in air (Rao \& Muller, 2007). Hence for the enriched air, $7 \% \mathrm{~N}_{2}$ in syngas, which can achieve full conversion per pass at 60 bar was chosen for the LTMS process.

\subsection{Simulation of the Overall LTMS Process}

The optimized operation conditions for the two reactors were put together as an overall LTMS process. Two scenarios were considered; one involving 'normal' airblown ATR $\left(0.21 \mathrm{O}_{2}: 0.79 \mathrm{~N}_{2}\right)$ and the other involving an $\mathrm{O}_{2}$ enriched air-blown-blown $\left(\begin{array}{lll}0.70 & \mathrm{O}_{2}: 0.30 & \mathrm{~N}_{2}\end{array}\right)$ system. Figure 9 shows the Aspen HYSYS flow-sheet for the overall standard LTMS process for an enriched airblown ATR. The set-up in the Figure 9 differs from the normal air-blown system by the inclusion of a PSA unit for enriching the air.

The details of the selected operating conditions used for the calculation is tabulated in Table 1 . The partial oxidation was carried out at $1200{ }^{\circ} \mathrm{C}$ and effluent from the ATR cooled down to $30{ }^{\circ} \mathrm{C}$ in both systems. The 20 bar $\mathrm{N}_{2}$ containing syngas produced was compressed to either 60 or 100 bar in the compressor where adiabatic efficiencies were specified to $75 \%$. Starting with 3990 $\mathrm{kmol} / \mathrm{h} \mathrm{CH}_{4}$ flow, the normal air-blown system yielded $3842 \mathrm{kmol} / \mathrm{h} \mathrm{MeOH}$ at 100 bar syngas pressure while that with the enriched air-blown yielded $3919 \mathrm{kmol} / \mathrm{h} \mathrm{MeOH}$ at 60 bar.

The heat/energy flow for the two systems is shown in Table 2. The negative signs in the table represent heating demands, while the positive represented heat release. For the normal air-blown system, a surplus (after recovery) of $7.68 \times 10^{8} \mathrm{~kJ} / \mathrm{h}$ heat was released as calculated from the heating and cooling. The total energy demand for the compressors was estimated to be $2.80 \times 10^{8} \mathrm{~kJ} / \mathrm{h}$ or 2270 $\mathrm{MJ} /$ ton $\mathrm{MeOH}$ product for the air-blown system. For the enriched air-blown system, a surplus (after recovery) of $6.10 \times 10^{8} \mathrm{~kJ} / \mathrm{h}$ heat was released when the heating and cooling streams were considered. The energy demand due to compression was estimated to be $1.23 \times 10^{8} \mathrm{~kJ} / \mathrm{h}$ or 983 $\mathrm{MJ} / \mathrm{ton} \mathrm{MeOH}$ product required for the enriched air-blown system. Overall the heat demand is covered by the surplus heat in both air-blown ATR systems. 


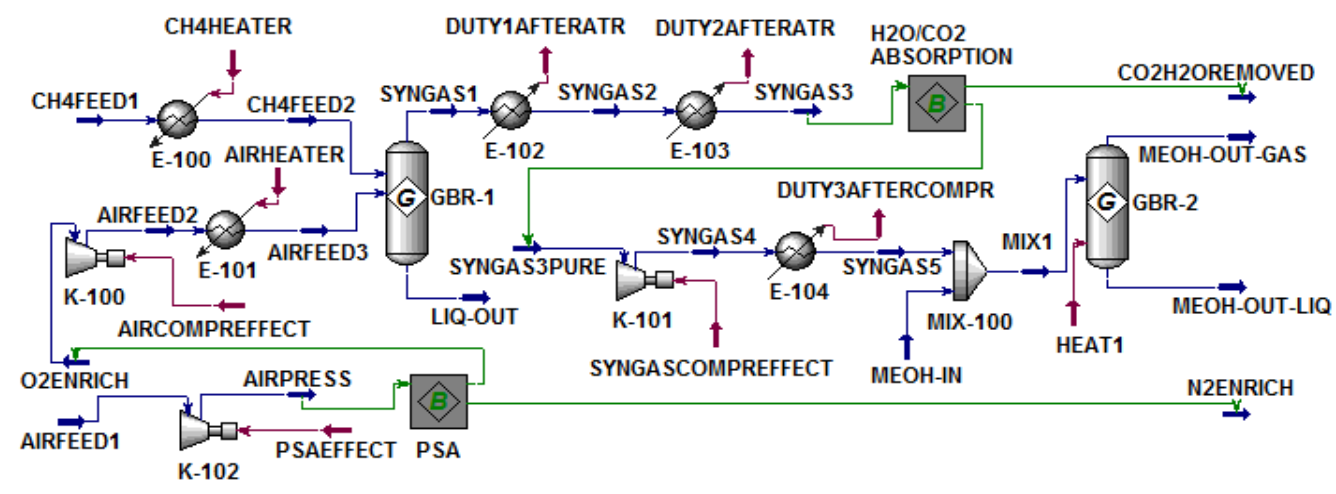

Figure 9. Aspen HYSYS flow-sheet for the overall standard LTMS process

Table 1. Specifications of Operation Conditions for the Overall LTMS Process as used in Figure 9

\begin{tabular}{|c|c|c|c|c|c|c|c|c|}
\hline \multicolumn{5}{|c|}{ Air-blown ATR system } & \multicolumn{4}{|c|}{ Enriched air-blown ATR system } \\
\hline Parameter & $\begin{array}{c}\text { Molar flow } \\
(\mathbf{k m o l} / \mathbf{h})\end{array}$ & $\begin{array}{l}\text { Pressure } \\
\text { (bar) }\end{array}$ & $\begin{array}{c}\text { Temperature } \\
\left({ }^{\circ} \mathrm{C}\right)\end{array}$ & $\begin{array}{c}\text { Main } \\
\text { composition }\end{array}$ & $\begin{array}{c}\text { Molar flow } \\
(\mathbf{k m o l} / \mathbf{h})\end{array}$ & $\begin{array}{l}\text { Pressure } \\
\text { (bar) }\end{array}$ & $\begin{array}{c}\text { Temperature } \\
\left({ }^{\circ} \mathrm{C}\right)\end{array}$ & $\begin{array}{c}\text { Main } \\
\text { Composition }\end{array}$ \\
\hline $\mathrm{CH}_{4} \mathrm{Feed}$ & 3990 & 20 & 20 & $1 \mathrm{CH}_{4}$ & 3990 & 20 & 20 & $1 \mathrm{CH}_{4}$ \\
\hline $\mathrm{CH}_{4} \mathrm{Feed} 2$ & ،, & ‘ & 1200 & ،, & ،, & ‘’ & 1200 & ، \\
\hline AirFeed & 9500 & 1.01 & 20 & $0.21 \mathrm{O}_{2}: 0.79 \mathrm{~N}_{2}$ & 14250 & 1.01 & 20 & $0.21 \mathrm{O}_{2}: 0.79 \mathrm{~N}_{2}$ \\
\hline AirPress & - & - & - & - & ، & 1.50 & 66.5 & ", \\
\hline $\mathrm{O}_{2}$ Enrich & - & - & - & - & 2850 & 1.10 & 67 & $0.70 \mathrm{O}_{2}: 0.30 \mathrm{~N}_{2}$ \\
\hline AirFeed 2 & 9500 & 20 & 515 & $0.21 \mathrm{O}_{2}: 0.79 \mathrm{~N}_{2}$ & “, & 20 & 595 & ", \\
\hline AirFeed3 & ‘, & “' & 1200 & ،, & ‘, & ‘ & 1200 & ،, \\
\hline Syngas1 & 19375 & ، & 1356 & $\begin{array}{c}0.20 \mathrm{CO}: 0.40 \mathrm{H}_{2} \\
: 0.39 \mathrm{~N}_{2}\end{array}$ & 12727 & ، & 1439 & $\begin{array}{c}0.31 \mathrm{CO}: 0.62 \\
\mathrm{H}_{2}: 0.07 \mathrm{~N}_{2}\end{array}$ \\
\hline Syngas 2 & ، & ، & 652 & ، & ، & ، & 687 & ، \\
\hline Syngas3 & ، & ، & 30 & ، & ‘, & ‘, & 30 & ،, \\
\hline Syngas3pure & - & - & - & - & 12678 & 20 & 33.5 & ،, \\
\hline Syngas4 & 19375 & 100 & 265 & $\begin{array}{c}0.20 \mathrm{CO}: 0.40 \mathrm{H}_{2}: 0 . \\
39 \mathrm{~N}_{2}\end{array}$ & ‘, & 60 & 186 & “' \\
\hline Syngas 5 & ، & ، & 30 & ، & ‘, & 60 & 100 & “' \\
\hline Mix 1 & ‘, & ،, & " & ، & ‘, & ' & ', & ،, \\
\hline $\begin{array}{r}\text { MeOH out } \\
\text { (Liquid+Gas) }\end{array}$ & 11642 & ، & 100 & $\begin{array}{c}0.33 \mathrm{CH}_{3} \mathrm{OH}: \\
0.64 \mathrm{~N}_{2}\end{array}$ & 4839 & ، & ، & $\begin{array}{c}0.81 \mathrm{CH}_{3} \mathrm{OH}: \\
0.18 \mathrm{~N}_{2}\end{array}$ \\
\hline
\end{tabular}

Table 2. Heat/Energy flow for the overall LTMS process in reference to Figure 9

\begin{tabular}{r|cc} 
Heating & $\begin{array}{c}\text { Air-blown } \\
\left(\mathbf{1 0}^{\mathbf{k} J / h}\right)\end{array}$ & $\begin{array}{c}\text { Enriched-air } \\
\left(\mathbf{1 0}^{\boldsymbol{6}} \mathbf{k J} / \boldsymbol{h}\right)\end{array}$ \\
\hline CH4HEATER (-) & 306 & 306 \\
AIRHEATER (-) & 219 & 60.2 \\
DUTY1AFTERATR (+) & 451 & 315 \\
DUTY2AFTERATR (+) & 366 & 252 \\
DUTY3AFTERCOMPR (+) & 141 & 32.2 \\
Compression & 335 & 377 \\
HEAT1 (+) & & \\
AIRCOMPREFFECT & - & 19.4 \\
SYNGASCOMPREFFECT & 144 & 47.6 \\
\end{tabular}

\section{Discussion of the Process}

The air-blown ATR process for LTMS technology differ from conventional $\mathrm{MeOH}$ synthesis technology by the inclusion of $\mathrm{N}_{2}$ diluent. The use of normal air for syngas production presents a cheaper alternative rather than a cryogenic $\mathrm{O}_{2}$ which is more capital intensive. Alternatively, cheaper $\mathrm{O}_{2}$ enriched air can be produced either by PSA or membrane separation technologies.
PSA was preferred for the model since membrane separation is usually economical only at small scale (i.e. $<20$ ton/day). When an enriched air is used, the cost of production using a PSA will be cheaper than the use of a cryogenic air separation (Rao \& Muller, 2007) considering the $70 \% \mathrm{O}_{2}$ (in air) purity estimated for the partial oxidation in this work.

The exothermic partial oxidation reaction for the syngas production generates excess energy. The reaction specified at $1200{ }^{\circ} \mathrm{C}$ indicates outlet temperatures between $1350-1440{ }^{\circ} \mathrm{C}$. This can raise concerns about the choice of the reactor material. Nevertheless, a typical ATR reactor has a burner operating above $2000^{\circ} \mathrm{C}$ (Dybkjaer, 1995), and hence a $1440{ }^{\circ} \mathrm{C}$ stream outlet with a good heat transfer does not pose extra danger compared to the existing reactors. It is also important to note that the partial oxidation process is already a commercial process in ammonia plants (York et. al., 2003) and considering the high operating temperature, the conversions obtained are practically close to equilibrium.

Furthermore, the difference in energy input and output due to heating indicated surplus of $7.68 \times 10^{8}$ and $6.10 \times 10^{8} \mathrm{~kJ} / \mathrm{h}$ released in the normal air-blown and the 
enriched air-blown processes respectively. This indicated that heat generated in the process was enough to cover the heating demand in the total process. If the surplus energy is not recovered, the heat lost will be higher in the normal air-blown system. The surplus energy can however be used for power production for example in steam turbines (Ganapathy \& Faulkner, 2002). The energy demand will therefore be due to feed compression, which can be reduced by the power generated from the surplus energy.

Thermodynamically, a full conversion per pass can be attained at lower temperatures below $120{ }^{\circ} \mathrm{C}$. This however, depended on the partial pressure of the syngas components. When $39 \% \mathrm{~N}_{2}$ (from normal air-blown) in syngas was used as feed, full syngas conversion was possible at 100 bar. One disadvantage is the need for larger reactor volumes due to the space occupied by the $\mathrm{N}_{2}$ diluent. However, with the enrichment of the air, same conversion could be attained with $7 \% \mathrm{~N}_{2}$ in syngas at $60 \mathrm{bar}$. The energy demand from compression relative to $\mathrm{MeOH}$ production was therefore estimated to 2270 and $983 \mathrm{MJ} /$ ton $\mathrm{MeOH}$ product for the normal airblown and the enriched air-blown systems respectively.

The optimized LTMS process was put together and a complete process design proposed. The Figure 10 shows a simplified diagram of the proposed air-blown LTMS process. Even though full syngas conversion can be achieved at $100{ }^{\circ} \mathrm{C}$ and $60 \mathrm{bar}$, there are a few experimental drawbacks. $\mathrm{H}_{2} \mathrm{O}$ and $\mathrm{CO}_{2}$ for example are catalyst poisons, and are required to be less than $10 \mathrm{ppm}$ (Liu et. al., 1988; Ohyama, 2003). The amount of methoxide diminishes by reacting with $\mathrm{H}_{2} \mathrm{O}$ and $\mathrm{CO}_{2}$ to produce hydroxide and carbonate respectively. As a results, there is a need to have an absorbing unit to remove $\mathrm{H}_{2} \mathrm{O}$ and $\mathrm{CO}_{2}$ from the syngas. Moreover, as $\mathrm{MeOH}$ is separated from the product stream some of the catalyst system which has undergone recycling can be reintroduced into the reactor. Overall, the air-blown ATR for a complete LTMS process design is a promising process for cheaper $\mathrm{MeOH}$ production.

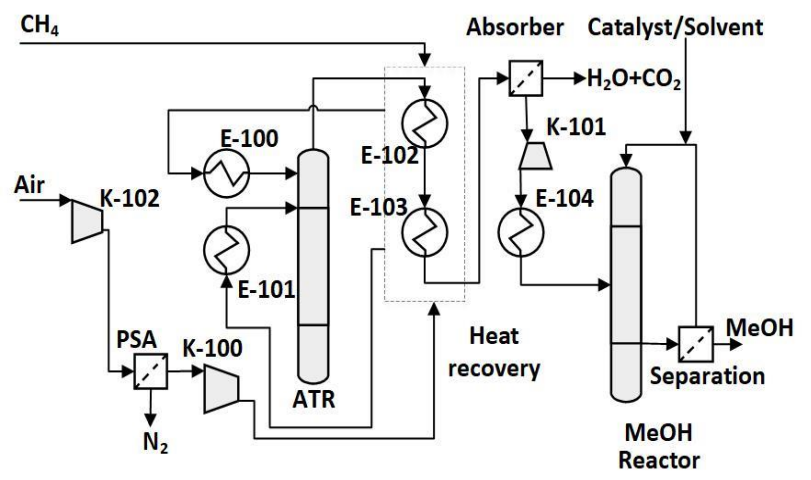

Figure 10. Simplified flow diagram of a complete LTMS process design

\section{Conclusion}

Simulations and optimizations of air-blown ATR and $\mathrm{MeOH}$ synthesis were performed to design a complete LTMS process. A normal air and an $\mathrm{O}_{2}$ enriched airblown ATR were optimized for syngas production in the low temperature $\mathrm{MeOH}$ synthesis process. Overall, the air-blown system containing $39 \% \mathrm{~N}_{2}$ (from air) in the syngas required about 100 bar to achieve full conversion, while the enriched air-blown system which contained $7 \% \mathrm{~N}_{2}$ in syngas could achieve same conversion at 60 bar. In both cases, the energy generated in the process was enough to cover the heating demand in the total process. When the surplus energy is not recovered, the heat lost will be higher in the normal airblown system than the enriched air-blown system. The energy required for compression was therefore estimated to be 2270 and $983 \mathrm{MJ} /$ ton $\mathrm{MeOH}$ product for the normal air and enriched air-blown systems respectively. An overall design was proposed based on the optimized conditions for the air-blown process.

\section{References}

C. Ahoba-Sam, Boodhoo, K., Olsbye, U., \& Jens, K.-J. 2018. Tailoring $\mathrm{Cu}$ Nanoparticle Catalyst for Methanol Synthesis Using the Spinning Disk Reactor. Materials, 11(1), 154.

C. Ahoba-Sam, Olsbye, U., \& Jens, K.-J. 2017. The Role of Solvent Polarity on Low-Temperature Methanol Synthesis Catalyzed by $\mathrm{Cu}$ Nanoparticles. Frontiers in Energy Research, 5(15). doi:10.3389/fenrg.2017.00015

C. Ahoba-Sam, Olsbye, U., \& Jens, K.-J. 2018. Low temperature methanol synthesis catalyzed by copper nanoparticles. $\begin{array}{llll}\text { Catalysis } & \text { Today, } & 299, & 112-119 .\end{array}$ doi:https://doi.org/10.1016/j.cattod.2017.06.038

J. A. Christiansen. (1919). U.S. Patent 1,302,011.

I. Dybkjaer. 1995. Tubular reforming and autothermal reforming of natural gas - an overview of available processes. Fuel Processing Technology, 42(2), 85-107. doi:https://doi.org/10.1016/0378-3820(94)00099-F

V. Ganapathy, \& Faulkner, L. 2002. Industrial Boilers and Heat Recovery Steam Generators. Boca Raton: CRC Press.

J. B. Hansen, \& Højlund Nielsen, P. E. 2008. Methanol Synthesis. In G. Ertl, H. Knozinger, F. Schuth, \& J. Weitkamp (Eds.), Handbook of Heterogeneous Catalysis (Vol. 6, pp. 29202949). Weinheim, Germany: Wiley-VCH Verlag GmbH \& Co. KGaA.

J.-P. Lange. 2001. Methanol synthesis: a short review of technology improvements. Catalysis Today, 64(1), 3-8. doi:https://doi.org/10.1016/S0920-5861(00)00503-4

Z. Liu, Tierney, J. W., Shah, Y. T., \& Wender, I. 1988. Kinetics of two-step methanol synthesis in the slurry phase. Fuel Processing Technology, 18(2), 185-199. doi:http://dx.doi.org/10.1016/0378-3820(88)90095-1

M. Marchionna, Di Girolamo, M., Tagliabue, L., Spangler, M. J., $\&$ Fleisch, T. H. 1998. A review of low temperature methanol synthesis. Studies in Surface Science and Catalysis, Volume 119 , 539-544. doi:http://dx.doi.org/10.1016/S01672991(98)80487-4

S. Ohyama. 2003. Low-Temperature Methanol Synthesis in Catalytic Systems Composed of Copper-Based Oxides and Alkali Alkoxides in Liquid Media: Effects of Reaction Variables on Catalytic Performance. Topics in Catalysis, 22(3), 337-343. doi:10.1023/A:1023500725571 
S. Ohyama, \& Kishida, H. 1998. Physical mixture of $\mathrm{CuO}$ and $\mathrm{Cr} 2 \mathrm{O} 3$ as an active catalyst component for low-temperature methanol synthesis via methyl formate. Applied Catalysis A: General, 172(2), 241-247. doi:http://dx.doi.org/10.1016/S0926-860X(98)00135-5

G. A. Olah. 2005. Beyond Oil and Gas: The Methanol Economy. Angewandte Chemie International Edition, 44(18), 26362639. doi:10.1002/anie.200462121

U. Olsbye, Svelle, S., Bjørgen, M., Beato, P., Janssens, T. V. W. Joensen, F., . . Lillerud, K. P. 2012. Conversion of Methanol to Hydrocarbons: How Zeolite Cavity and Pore Size Controls Product Selectivity. Angewandte Chemie International Edition, 51(24), 5810-5831. doi:10.1002/anie.201103657

D.-Y. Peng, \& Robinson, D. B. 1976. A New Two-Constant Equation of State. Industrial \& Engineering Chemistry Fundamentals, 15(1), 59-64. doi:10.1021/1160057a011

P. Rao, \& Muller, M. 2007. Industrial Oxygen, Its Generation and Use. Paper presented at the Energy Efficiency in Industry.

A. P. E. York, Xiao, T., \& Green, M. L. H. 2003. Brief Overview of the Partial Oxidation of Methane to Synthesis Gas. Topics in Catalysis, 22(3), 345-358. doi:10.1023/A:1023552709642 